\title{
Moninaisuudessa vuosikirjan vahvuus ja heikkous
}

Tosse, S., Falkencrone, P., Puurula, A. \& Bergstedt, B. (toim.) 2000. Reforms and policy. Adult education research in Nordic countries. Trondheim: Tapir Academic Press.

Uusin, viisitoista artikkelia sisältävä, aikuiskasvatuksen pohjoismainen vuosikirja on otsikoitu "Reforms and Policy". Kirjan otsikko orientoi lukijan erilaisten Pohjoismaissa toteutettujen koulutusreformien ja koulutuspoliittisten kehityssuuntien jäljille. Kirjan viisi ensimmäistä artikkelia kuvaavatkin erilaisia kansallisia koulutuksellisia reformeja. Sen sijaan loput artikkelit liittyvät väljemmin kirjan otsikkoon.

\section{Ensimmäisessä artikkelissa} Sigvart Tosse kuvaa norjalaisen aikuiskoulutuksen kehitystä aina sivistyksellisen ja taloudellisen kasvun edistämistä tukevan koulutuspolitiikan ajoista aikuiskoulutuksen nykyiseen missioon: ammatillisen koulutuksen edistämiseen. Tätä aikuiskoulutuksen ammatillista orientaatiota on valtio voimakkaasti tukenut ja 1990-luvulta alkaen aikuiskoulutus onkin ollut merkittävä osa työvoimapolitiikkaa. Niinpä valtiolla on ollut merkittävä rooli aikuiskasvatuksen aseman ja kehityksen muokkaajana.

\section{Kirjan toisessa} artikkelissa Risto Rinne ja Markku Vanttaja erittelevät suomalaisen aikuiskasvatuksen kehityssuuntia. 1970-80 -lu- vuilla aikuiskasvatuksen keskeisempänä tavoitteena oli edistää koulutuksellista tasaarvoa kohdentamalla koulutus niille kansalaisille, joilla oli vähiten ammatillista koulutusta. Nykyisin tämän tasa-arvopyrkimyksen on syrjäyttämässä työmarkkinaorientoitunut aikuiskoulutus. Tällöin aikuiskasvatuksen keskeisimpänä tehtävänä on sopeuttaa työväestöä jatkuvasti muuttuviin yhteiskunnallisiin oloihin. Samalla aikuiskoulutus on myös kaupallistunut. Artikkelin lopuksi kirjoittajat kritisoivat koulutuspolitiikkaa siitä, että se hyväksyy tilanteen, mikä on jo vuosia näkynyt tilastoissa: eniten aikuiskoulutuksesta hyötyvät ne, jotka ovat jo korkeasti koulutettuja. Ehkä olisi koulutuspoliittisin keinoin syytä kiinnittää (jälleen) huomiota koulutukselliseen tasa-arvoon.

\section{Per-Olof Thång ja Gun-} Britt Wärwik käsittelevät artikkelissaan Ruotsissa toteutettuja uudistuksia, joilla on pyritty lisäämään aikuisten osallistumismahdollisuuksia aikuiskoulutukseen. Vaikka kirjoittajien näkökulma on aikuisten motiiveissa ja intresseissä osallistua aikuiskoulutukseen, päätyvät he samansuuntaisiin havaintoihin kuin Rinne ja Vanttajakin. He havaitsivat haastattelututkimuksessaan, että valtaosa vastanneista koki aikuiskoulutuksen työmarkkinoiden välineenä sopeuttaa työntekijä lisääntyneisiin kvalifikaatiovaatimuksiin. Haastatellut myös kritisoivat korkeita muodollisia kvalifikaatiovaa- timuksia vastaan, sillä käytännössä hei-koimmillakin kvalifikaa-tioilla tulee työssä toimeen. Sekä Suomessa että Ruotsissa näyttäisi olevan vallalla julkinen (valtion ylläpitämä) retoriikka, joka ihannoi koulutusoptimismia ja näin pyrkii aina vain kvalifikoidumman työvoiman tuottamiseen.

\section{Sekä Hannele Salminen} että Heidi Engesbak kuvaavat artikkeleissaan yksittäisiä, mutta kansallisesti merkittäviä koulutuksellisia reformeja: Salminen ammattikorkeakoulujärjestelmän syntymistä Suomeen ja Engesbak ns. Reformi 94 vaikutuksia norjalaiselle keskiasteen koulutukselle. Salminen esittää erilaisia syitä, kuten tarpeen uudistaa koulutusjärjestelmää ja ammatillisen koulutuksen kansainvälisen vertailun helpottamisen, ammattikorkeakoulujärjestelmän perustamisen taustalla. Ammattikorkeakoulujen kehittymiseen vaikutti myös ns. akateeminen noste (academic drift), jonka "toisesta aallosta" voidaan pitää esimerkkinä viime aikaista keskustelua esimerkiksi ammattikorkeakoulujen jatkotutkinnoista. Engesbak tarkastelee artikkelissaan norjalaista keskiasteen koulutuksen muutosta, joka nimettiin Reformi 94. Uudistus paransi 16-19 -vuotiaiden asemaa ammatillisessa koulutuksessa, mutta aikuiset jäivät tämän uudistuksen ulkopuolelle. Niinpä reformi ei parantanut aikuisten mahdollisuuksia lisätä ammatillisia kompetenssejaan. 


\section{Kirjan loput artikkelit} ovat temaattisesti alkua epäyhtenäisempi kokonaisuus. Horsdalin, Filanderin sekä Heikkisen ja Laihon artikkeleissa esitetään - tavalla tai toisella - aikuiskoulutuksen erääksi keskeiseksi tehtäväksi tarjota mahdollisuuksia (ammatillisen) identiteetin rakentamiseen. Marianne Horsdal tarkastelee narratiivisesta näkökulmasta dynaamisen yhteiskunnan ja yksilöllistymisen välistä vuorovaikutusta. Horsdalin mukaan nyky-yhteiskunnassa oman elämän suunnittelu ja sen refleksiivinen rakentaminen ovat elinikäisiä projekteja. Näin hän sitoo individualisaation osaksi elinikäistä oppimista. Koska ihminen rakentaa identiteettiään (moni)kulttuurisissa narratiiveissa, tarvitaan tilaa dialogille. Juuri aikuiskoulutus on eräs keskeinen areena tälle dialogille. Karin Filander esittää artikkelissaan, että aikuiskasvatustieteessä tutkimuksen keskiössä on harvoin toimija. Aikuiskouluttajien olisikin luotava oppimistilanteita, joissa toimijat voivat analysoida omaa elämäänsä ja niitä erilaisia kulttuurisia diskursseja, joita he aktiivisesti rakentavat. Näitä oppimistiloja toimijat voivat käyttää paikantaakseen itsensä epävarmuuksien aikana. Aikuiskasvatuksen eräänä tehtävä on tarjota toimijoille tulkitsevia yhteisöjä ja niitä oppimistiloja, joissa he voivat rakentaa omia kulttuurisia narratiivejaan.

\section{Anja Heikkinen ja}

Kristiina Laiho kritisoivat artikkelissaan elinikäisen oppimisen diskurssin hallitsevuutta koulutuspoliittisessa keskustelussa. He tuovat sen rinnalle yhteiskunnallisen osallis- tumisen käsitteen. Heidän artikkelinsa perustuu Lifequalprojektiin, jonka juuret ovat juuri edellä mainitussa elinikäisen oppimisen diskursiivisessa hallitsevuudessa. Sen lisäksi, että artikkeli esittää vaihtoehtoisia näkökulmia elinikäiselle oppimiselle, se käy myös kuvauksena kansallisten erojen tuottamista haasteista kansainvälisissä tutkimusprojekteissa. Yhteiskunnallista osallistumista kuvataan nuorten työpajatyöskentelyssä. Työpajat on tarkoitettu nuorille, jotka ovat keskeyttäneet omat (ammatilliset) opintonsa. Työpajat ovat siis nuorille tiloja suunnitella tulevaisuuttaan. Näin nuoret saavat kokemuksen yhteiskunnallisesta osallistumisesta sen sijaan, että heidät pakotettaisiin työllisyyskursseille tai työttömiksi. Edellä mainitut kolme artikkelia sivuavat toisiaan siten, että juuri Heikkisen ja Laihon tutkimat työpajat voidaan nähdä Horsdalin tarkoittamina omaelämänkerrallisten narratiivien rakentamistiloina tai Filanderin peräänkuuluttamana oppimistiloina, joissa voidaan rakentaa ja (uudelleen)tulkita omia kulttuurisia kertomuksia.

\section{Lisäksi kirjassa kuvataan} etäopetuksen historiallista kehitystä ja virtuaalisopetuksen nykyisiä haasteita Norjassa (Torstein Rekkedal), tietotekniikan vaikutuksia pk-yrityksissä (Tarja Tikkanen), epämuodollisen koulutuksen ja työelämän välistä suhdetta (Bjarne Wahlgren), johtamiskoulutusta historiallisesta ja kulttuurisesta näkökulmasta (Juha Kettunen), itseohjautuvan oppimisen autonomisuutta ja yhteisöllisyyttä (Leena Ahteenmäki-Pelkonen) sekä norjalaisen kansanopistojen syntyyn merkittävästi vaikuttaneen Nicolai Grundtvigin koulutuksellisia näkemyksiä (Ove Korsgaard). Kirjan päättää artikkeli, joka visioi elinikäistä oppimista 2020luvun Pohjoismaissa (Gunnar Grepperud \& Odd Einar Johansen). Vaikka tässä artikkelissa pohdintaankin monipuolisesti Pohjoismaiden koulutuspoliittisia kehityssuuntia sekä laajempia yhteiskunnallisia trendejä, tarjoaa se kuitenkin vain yhden mahdollisen skeenarion siitä, mitä tulevaisuudessa tapahtuu. Toki tällainen tulevaisuuden visiointi on mielenkiintoista luettavaa.

\section{Kirjaa voi suositella} erityisesti niille, joita kiinnostavat erilaiset aikuiskoulutuksen piirissä tehdyt reformit ja kokeilut. Artikkelien moninaisuus on sekä kirjan vahvuus että heikkous. Lähtökohdiltaan ja lähestymistavoiltaan erilaiset artikkelit antavat kattavan kuvan aikuiskoulutuksen eri ulottuvuuksista ja tehtävistä Pohjoismaissa. Lisäksi kirjassa esitellään paljon käytännön esimerkkejä aikuiskoulutuksen eri toteuttamismahdollisuuksista, mikä laajentaa kirjan lukijakuntaa käytännön toimijoihin ja myös erilaisten koulutuksellisten hankkeiden suunnittelijoihin ja päätöksentekijöihin. Paikoitellen kuitenkin tuntuu, että artikkelien yhteinen nimittäjä lienee paitsi lukijalta, myös toimituskunnalta olevan kadoksissa. Niinpä lukijalle, olipa hän sitten käytännön toimija, tutkija tai päätöksentekijä, jää melko epäselvä kokonaisuus luettavakseen.

\section{Jani Ursin}

